\title{
Simultaneous Differential Determination of Inorganic Acid and Nitrate in DMF Solution by Nonaqueous Conductometric Titration with Sodium Tetrahydroborate
}

\author{
Takayoshi FujINo* and Hayao Noguchi \\ Department of Applied Chemistry, Faculty of Science and Engineering, Kinki University \\ (3-4-1, Kowakae, Higashiosaka, Osaka 577-8502, JAPAN)
}

Edited by T. Oida, Kyoto Inst. Tec., and accepted August 26, 2002 (received for review February 18, 2002)

\begin{abstract}
Generally the degree of electrolytic dissociation of an aqua (protic solvent) is larger than that of a nonaqueous solvent (aprotic solvent). And the electric conductivity of an inorganic salt dissolved in a nonaqueous solvent is smaller than in an aqueous solution. Therefore the differential of electric conductivity was conspicuous because electric conductivity when dissolved with a solute is low in a nonaqueous solvent. The differential determination by conductometric titration of mixed solution of inorganic salts was possible in a nonaqueous solvent such as N,N-dimethylformamide (DMF). The simultaneous differential determination of nitrate and inorganic acid in solution was conducted by nonaqueous conductometric titration with sodium tetrahydroborate (STHB) in DMF. Inflection points appeared on conductometric titration curves of nitrate and inorganic acid solution in DMF, and were due to differences in reactivity and acidity. The inflection points indicated concentrations of nitrate and inorganic acid simultaneously. STHB and $\mathrm{Al}\left(\mathrm{NO}_{3}\right)_{3}$ reacted at a mole ratio of $1: 3$, and $\mathrm{Co}\left(\mathrm{NO}_{3}\right)_{2}$ reacted at 1:2. It was considered that the reaction mole ratio of STHB and nitrate was fixed by the valence of the metal ion. In order to investigate the reaction mechanism, ions in the DMF solution and precipitates were identified during titration by fourier transformation infrared spectroscopy (FTIR), inductive coupling plasma emission spectrometry (ICP-AES) and the X-ray diffraction method (XRD). $10 \%$ water in the sample solution did not interfere with the titration. The determination limit was $0.01-0.005 \mathrm{~mol} \mathrm{dm}^{-3}$ with this method.
\end{abstract}

Key words: nonaqueous conductometric titration, sodium tetrahydroborate, inorganic acid and nitrate, simultaneous differential determination, N,N-dimethylformamide

\section{Introduction}

Nonaqueous titration data for nitrite, perchlorate and chloride have been reported (1-3) as also for nonaqueous conductometric titration of metal compounds and iodometry of metal hydride and differential determination of mixed inorganic acid with sodium tetrahydroborate (STHB) (4-9). STHB is often used as a reducing agent in electroless metal plating in metal surface treat- ment. A basicity aprotic solvent such as DMF or pyridine dissolves STHB. DMF dissolves various inorganic salts, an adduct or addition ion species such as the solvate is formed. The simultaneous differential determination of inorganic acid and nitrate in DMF solution was conducted. There are many cases that must analyze the sample solution while keeping watch on $\mathrm{pH}$ of the reaction bath and concentration-change of the metal salt in various kinds of manufacture lines one by one. Besides,

\footnotetext{
*Correspondence to: Takayoshi FuJINO, Department of Applied Chemistry, Faculty of Science and Engineering, Kinki University, 3-4-1, Kowakae, Higashiosaka, Osaka 577-8502, JAPAN

E-mail: taka-f@apch.kindai.ac.jp
} 
swiftness is demanded from the analysis. Examples such as the analysis of electrocoating and coating line are put up. Evaporation to dryness is done after having resolved with acid as nitric acid in analysis of real sample, and the sample is extracted with acid. And this method can develop for application to analysis of cation coating, anion coating and waste oil, and for the swiftness determination of content metallic element in cosmetics. Volumetric analysis is quick and simple, but separation requires much time. Furthermore simultaneous determination of two species of mixed salts is impossible in an aqueous solution. Simultaneous differential determination in this study with STHB in DMF was carried out by conductometric titration. The reaction of various inorganic salts with STHB is complicated, and the reaction mechanism was not closely investigated. It is thought that this reaction is a reaction competitive with the redox reaction and Lewis acid / Lewis base reaction. Therefore elucidation of the reaction mechanism is most important. The precipitate which was produced during titration was analyzed by FT-IR, $\mathrm{XRD}$ and ICP-AES, and the reaction mechanism was investigated.

\section{Experimental}

\section{$2 \cdot 1$ Reagents and Solutions}

All reagents were analytical grade commercial materials and used without further purification: DMF, $\mathrm{I}_{2}$, $\mathrm{NaBH}_{4}, \mathrm{Al}\left(\mathrm{NO}_{3}\right)_{3}, \mathrm{Y}\left(\mathrm{NO}_{3}\right)_{3}, \mathrm{Co}\left(\mathrm{NO}_{3}\right)_{2}, \mathrm{Ni}\left(\mathrm{NO}_{3}\right)_{2}$, $\mathrm{H}_{2} \mathrm{SO}_{4}$ and $\mathrm{HNO}_{3}$, etc. The reaction product was dried at $115^{\circ} \mathrm{C}$ for two hours after having been washed with acetone. DMF solution of STHB was standardized by conductometric titration with iodine in DMF (8).

\section{$2 \cdot 2$ Apparatus}

Conductivity was measured on a CM-60S conductivity meter (Toa Electronics Ltd.) equipped with a PP1042 electrode (Radiometer Co. Ltd.). Fourier-transformation infrared spectra were recorded on a $1760-\mathrm{X}$ spectrophotometer (Parkin-Elmer Co. Ltd.). An ICPAES made by Shimazu Co.(model ICP-1000 III) and an XRD by Rigaku Denki Co.(model MiniFlex) ware also used. The qualitative analysis of $\mathrm{NO}_{3}{ }^{-}, \mathrm{NO}_{2}{ }^{-}$and $\mathrm{Ni}^{2+}$ in aqueous solution were inspected by a reflex photometer (Merck RQflex).

\section{2·3 Titration Method}

All solutions for titration were adjusted to $0.05 \mathrm{M}$ $\left.(\mathrm{mol} \mathrm{dm})^{-3}\right)$. The computational complexity of this solution was introduced into a cell for conductometric titration, and the solution was diluted with DMF till the total volume became $20 \mathrm{~cm}^{3}$. The total volume was constant in the cell. The STHB solution was titrated while stirring by means of a magnetic stirrer. Titration velocity was constantly $0.50 \mathrm{~cm}^{3} \min ^{-1}$ at $25^{\circ} \mathrm{C}$.

\section{Results and Discussion}

\section{$3 \cdot 1$ Conductometric Titration of Nitrate}

Figure 1 shows the conductometric titration curves for nitrates with STHB in DMF. Bubbles and precipitates were observed in all cases. The colors of the precipitate and solution are shown in Table $\mathbf{1}$ and indicate the precipitate contained metal ions. After titration of nickel nitrate with STHB, the black precipitate was separated from the solution by means of a membrane filter. The precipitate after vacuum drying was analyzed by FT-IR by the $\mathrm{KBr}$ method. There was absorption of $\mathrm{NO}_{3}^{-}\left(1384 \mathrm{~cm}^{-1}\right)$ and $\mathrm{OH}^{-}\left(3448 \mathrm{~cm}^{-1}\right)$ on the spectra. Solubility in water, hot water and hydrochloric acid of the precipitate were examined. The precipitate did not dissolve in a water or hot water, but $\mathrm{NO}_{3}{ }^{-}$ion was detected in the solution. Light microscopy indicated a similar crystal type as in the case of hydroxylation nick-

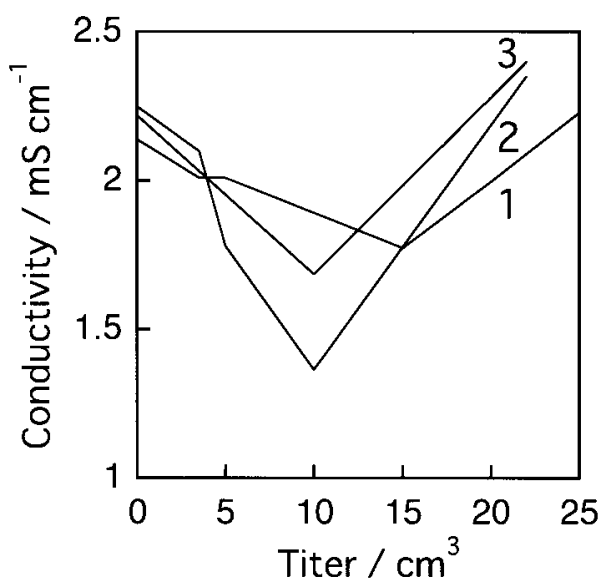

Fig. 1 Conductometric Titration Curves of Nitrate with Sodium Tetrahydroborate in DMF.

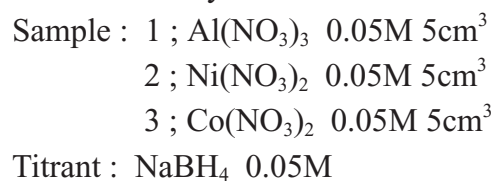


Table 1 Color Changing by the Reaction of Various Nitrate with Sodium Tetrahydroborate in DMF.

\begin{tabular}{lccc}
\hline \multicolumn{1}{c}{ Nitrate } & $\begin{array}{c}\text { DMF solution } \\
\text { of nitrate }\end{array}$ & $\begin{array}{c}\text { Precipitation } \\
\text { by the reaction }\end{array}$ & $\begin{array}{c}\text { Supernate liquid } \\
\text { after the reaction }\end{array}$ \\
\hline $\mathrm{Al}\left(\mathrm{NO}_{3}\right)_{3} \cdot 6 \mathrm{H}_{2} \mathrm{O}$ & colorless & white & colorless \\
\hline $\mathrm{Y}\left(\mathrm{NO}_{3}\right)_{2} \cdot 6 \mathrm{H}_{2} \mathrm{O}$ & colorless & white & colorless \\
\hline $\mathrm{Ni}\left(\mathrm{NO}_{3}\right)_{2} \cdot 6 \mathrm{H}_{2} \mathrm{O}$ & green & black & colorless \\
\hline $\mathrm{Co}\left(\mathrm{NO}_{3}\right)_{2} \cdot 6 \mathrm{H}_{2} \mathrm{O}$ & pink & black & colorless \\
\hline
\end{tabular}

el. The black precipitate dissolved well in hydrochloric acid. $\mathrm{NO}_{3}{ }^{-}$and $\mathrm{Ni}^{2+}$ ion were detected with a photometer. The $\mathrm{NO}_{3}{ }^{-}$concentration in the solution was the same as when dissolved in water. No effervescence or color change was seen, so that no ligand substitution reaction may occur. The reaction of nitric acid and STHB was as follows.

$$
\begin{aligned}
& 2 \mathrm{DMF}\left[\mathrm{HNO}_{3}\right]+2 \mathrm{DMF}\left[\mathrm{NaBH}_{4}\right] \\
& \quad \rightarrow 2 \mathrm{DMF}\left[\mathrm{NaNO}_{3}\right]+\mathrm{DMF} \cdot\left[\mathrm{B}_{2} \mathrm{H}_{6}\right]+2 \mathrm{H}_{2}
\end{aligned}
$$

\section{$3 \cdot 2$ Influence of Water on Titration}

Figure 2 shows that $10 \%$ water did not interfere with the present titration, because water influenced only the shape of the conductometric titration curve and the inflection points did not disappear. The conductometric

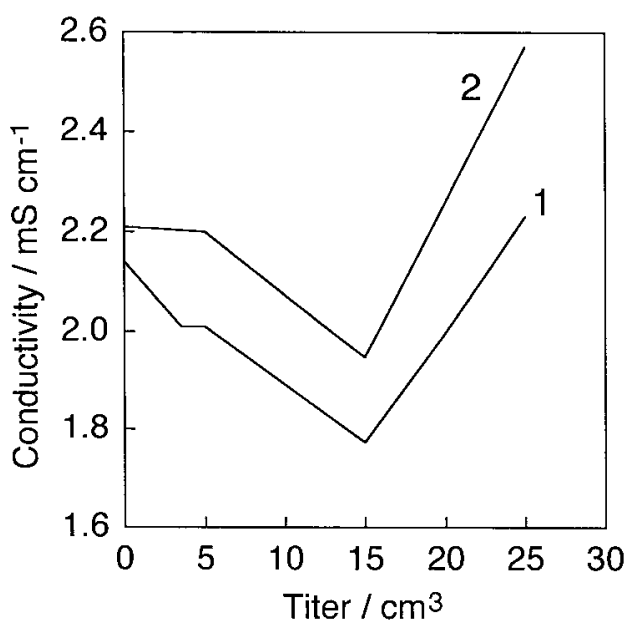

Fig. 2 Influence of Water on Conductometric Titration of Aluminum Nitrate with Sodium Tetrahydroborate in DMF.

Sample : $1 ; \mathrm{Al}\left(\mathrm{NO}_{3}\right)_{3} \quad 0.05 \mathrm{M} \mathrm{5 \textrm {cm } ^ { 3 }}$

$$
2 ; 1+10 \%-\mathrm{H}_{2} \mathrm{O}
$$

Titrant: $\mathrm{NaBH}_{4} \quad 0.05 \mathrm{M}$ titration curve showed a clear inflection point. Effervescence was recognized during titration, and it was hydrogen gas as having reported (9) the reaction of inorganic acids and STHB already. In this case it is thought that the water acted as acid for STHB.

\section{$3 \cdot 3$ Conductometric Titration of Nitrate and Nitric Acid}

Figure 3 shows conductometric titration curves for nitric acid and nickel nitrate with STHB. The color in the cell became gray after a black precipitate was formed by reaction of nitrate with STHB in DMF, so that nickel nitrate first reacts with STHB, and nitric acid reacts next. The second inflection point was caused by nickel nitrate, and the third inflection point was caused by the total value of nickel nitrate and nitric acid. And the reaction ratio of STHB to nickel nitrate was 2:1. These inflection points determined the concentrations of nitric acid and nickel nitrate in the sample solution simultaneously. Because the gray precipitate products consisted in the cell after the titration ended, the precipitate was filtered. The black precipitate did not dissolve in water, but only the white precipitate did.

Figure 4 shows conductometric titration curves for nitric acid and aluminum nitrate with STHB. The second inflection point was caused by the reaction of STHB with aluminum nitrate, and the reaction ratio of STHB to aluminum nitrate was 3:1. The third inflection point was caused by total nitric acid and aluminum nitrate. The concentrations of nitric acid and aluminum nitrate were determined from the inflection points simultaneously. When a nitric acid and zinc nitrate solution was titrated with STHB, the conductometric titration curves showed inflection points. 


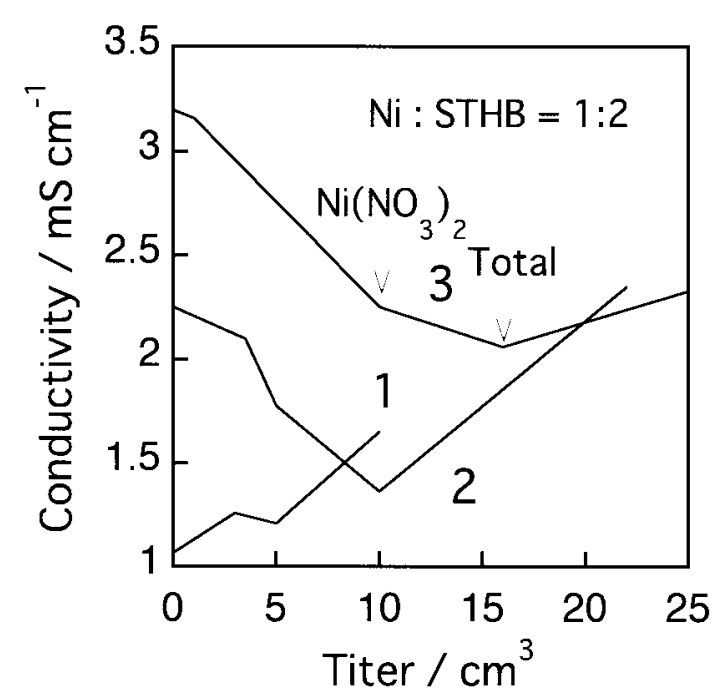

Fig. 3 Conductometric Titration Curves of Mixed Solution of Nitric Acid and Nickel Nitrate with Sodium Tetrahydroborate in DMF.

Sample : $1 ; \mathrm{HNO}_{3} 0.05 \mathrm{M} 5 \mathrm{~cm}^{3}$ $2 ; \mathrm{Ni}\left(\mathrm{NO}_{3}\right)_{2} \quad 0.05 \mathrm{M} 5 \mathrm{~cm}^{3}$ $3 ; 1+2$

Titrant: $\mathrm{NaBH}_{4} \quad 0.05 \mathrm{M}$

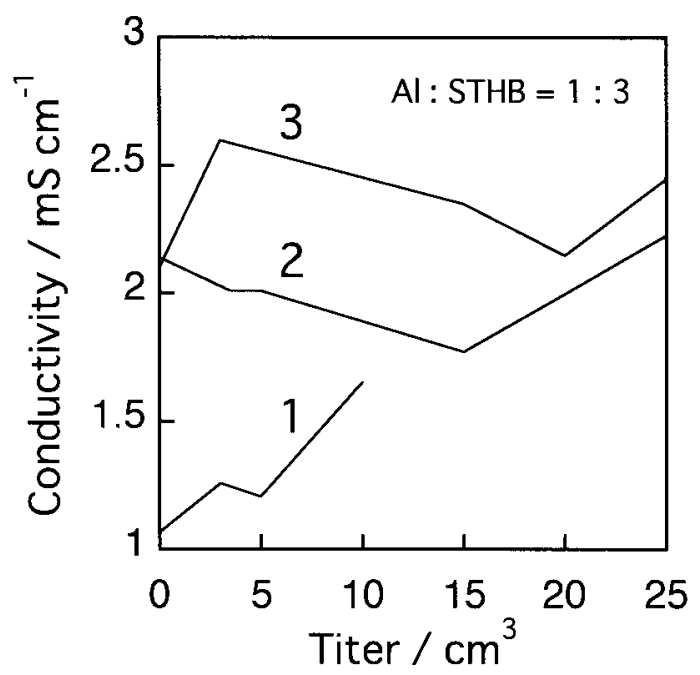

Fig. 4 Conductometric Titration Curves of Mixed Solution of Nitric Acid and Aluminum Nitrate with Sodium Tetrahydroborate in DMF.

Sample : $1 ; \mathrm{HNO}_{3} \quad 0.05 \mathrm{M} 5 \mathrm{~cm}^{3}$

$2 ; \mathrm{Al}\left(\mathrm{NO}_{3}\right)_{3} \quad 0.05 \mathrm{M} 5 \mathrm{~cm}^{3}$

$3 ; 1+2$

Titrant: $\mathrm{NaBH}_{4} \quad 0.05 \mathrm{M}$

\subsection{Conductometric Titration of Nitrate and Sulfuric Acid}

Figure 5 shows conductometric titration curves for sulfuric acid and nickel nitrate with STHB. The third inflection point was caused by nickel nitrate, and the fourth by total value. The first and second inflection points appeared as a result of the dissociation of nickel nitrate and generation of the precipitate. And the reaction ratio of nickel nitrate to STHB was 1:2.

Figure 6 shows the conductometric titration curves for sulfuric acid and aluminum nitrate with STHB. The first inflection point resulted from the precipitate. The second inflection point was caused by total aluminum nitrate with STHB as in reaction [1] and the third inflection point by reaction [2].

$$
\begin{aligned}
& 2 \mathrm{DMF}\left[\mathrm{H}_{2} \mathrm{SO}_{4}\right]+2 \mathrm{DMF}\left[\mathrm{NaBH}_{4}\right] \\
& \rightarrow 2 \mathrm{DMF}\left[\mathrm{NaHSO}_{4}\right]+\mathrm{DMF} \cdot \mathrm{B}_{2} \mathrm{H}_{6}+2 \mathrm{H}_{2} \\
& 2 \mathrm{DMF}\left[\mathrm{NaHSO}_{4}\right]+2 \mathrm{DMF}\left[\mathrm{NaBH}_{4}\right] \\
& \rightarrow \quad 2 \mathrm{DMF}\left[\mathrm{Na}_{2} \mathrm{SO}_{4}\right]+\mathrm{DMF} \cdot \mathrm{B}_{2} \mathrm{H}_{6}+2 \mathrm{H}_{2}
\end{aligned}
$$

Reaction of $\mathrm{Al}\left(\mathrm{NO}_{3}\right)_{3}$ and $\mathrm{H}_{2} \mathrm{SO}_{4}$ is not $15 \mathrm{~cm}^{3}$ of $\mathrm{Al}\left(\mathrm{NO}_{3}\right)_{3}$, and inflection point appears with $20 \mathrm{~cm}^{3}$. As for the reason, inflection point appeared with the point which $1 \mathrm{~mol}-\mathrm{Al}\left(\mathrm{NO}_{3}\right)_{3}$ and $1 / 2 \mathrm{~mol}-\mathrm{H}_{2} \mathrm{SO}_{4}\left(\mathrm{NaHSO}_{4}\right.$

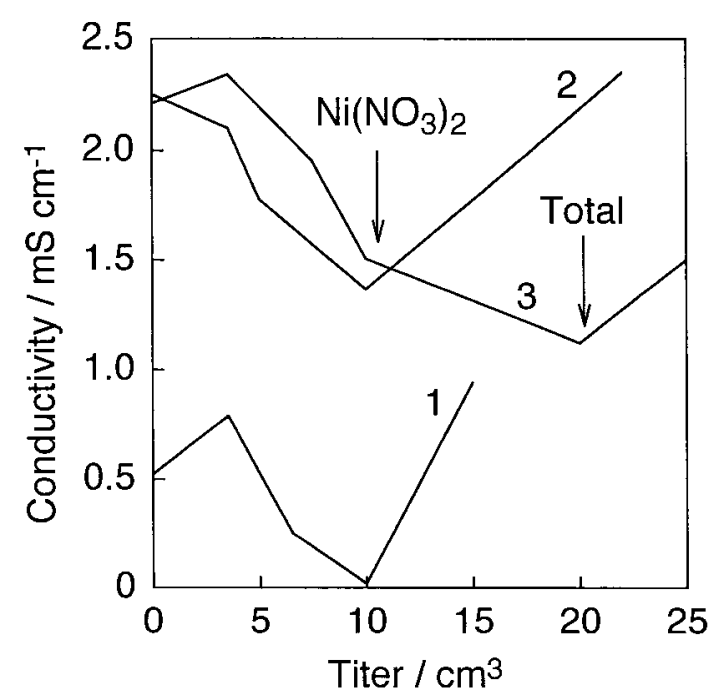

Fig. 5 Conductometric Titration Curves of Mixed Solution of Sulfuric Acid and Nickel Nitrate with Sodium Tetrahydroborate in DMF.

Sample : $1 ; \mathrm{H}_{2} \mathrm{SO}_{4} 0.05 \mathrm{M} 5 \mathrm{~cm}^{3}$

$$
\begin{aligned}
& 2 ; \mathrm{Ni}\left(\mathrm{NO}_{3}\right)_{2} \quad 0.05 \mathrm{M} 5 \mathrm{~cm}^{3} \\
& 3 ; 1+2
\end{aligned}
$$

Titrant: $\mathrm{NaBH}_{4} 0.05 \mathrm{M}$ 


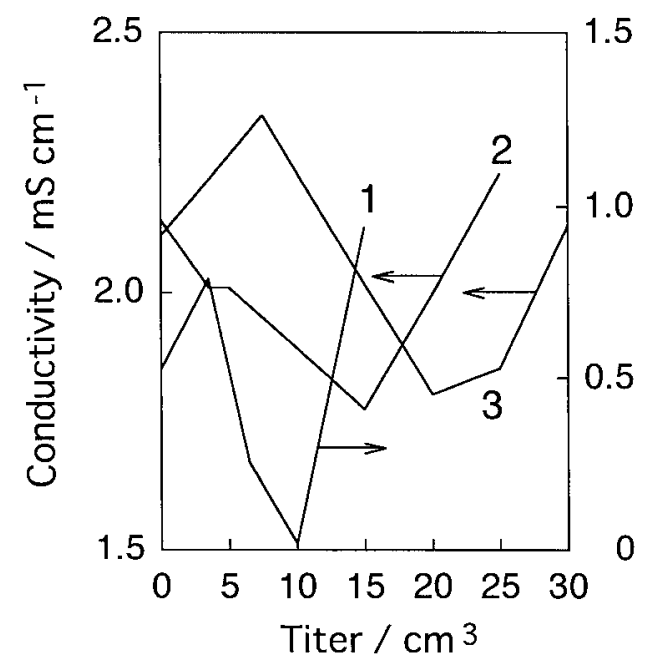

Fig. 6 Conductometric Titration Curves of Mixed Solution of Sulfuric Acid and Aluminum Nitrate with Sodium Tetrahydroborate in DMF.

$$
\begin{aligned}
\text { Sample : } & 1 ; \mathrm{H}_{2} \mathrm{SO}_{4} \quad 0.05 \mathrm{M} 5 \mathrm{~cm}^{3} \\
& 2 ; \mathrm{Al}\left(\mathrm{NO}_{3}\right)_{3} \quad 0.05 \mathrm{M} \mathrm{5 \textrm {cm } ^ { 3 }} \\
& 3 ; 1+2
\end{aligned}
$$

Titrant: $\mathrm{NaBH}_{4} \quad 0.05 \mathrm{M}$

generation) reacted to, and the inflection point of 25 $\mathrm{cm}^{3}$ was the point which all amount of substance reacted to.

Simultaneous differential determination was done with these points. And the reaction ratio of aluminum nitrate to STHB was 1:3. When aluminum nitrate and nickel nitrate were titrated with a DMF sulfuric acid solution, no effervescence or color change in the solution was seen. When titration of cobalt nitrate was done, the color of the solution changed to blue from pink. After titration of cobalt nitrate with STHB, the black precipitate was separated from the solution with a membrane filter. The precipitate after vacuum drying was analyzed by XRD. Because the precipitate was an amorphous substance, it was heated at $800^{\circ} \mathrm{C}$ (Fig. 7).

It was recognized that this baking substance was $\mathrm{Co}_{3}\left(\mathrm{BO}_{3}\right)_{2}$. The reaction product was divided in order to analyze the compound contained in the solution after reaction ended. The filtrate was distilled under the reduced pressure, and the XRD pattern of the residue is shown in Fig. 8. The residue was $\mathrm{NaNO}_{3}$.

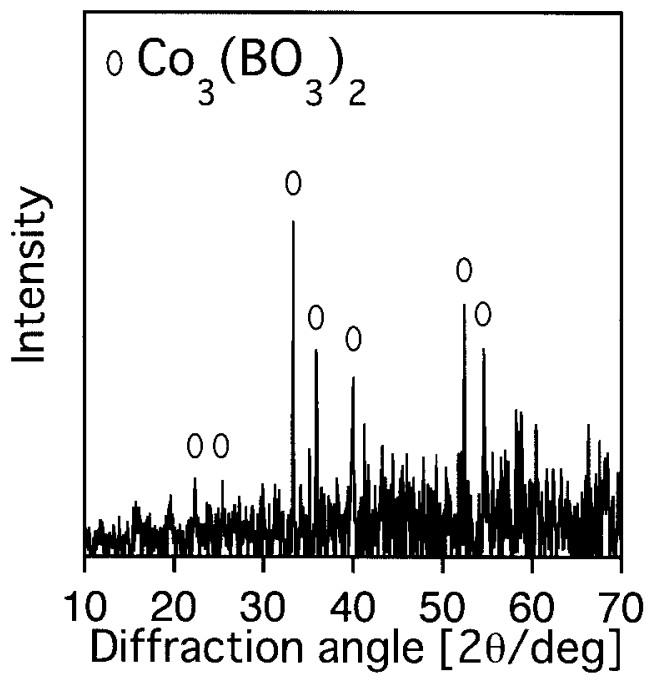

Fig. 7 X-ray Diffraction Pattern of the Residue after Heating Precipitation Product of Cobalt (II ) at $800^{\circ} \mathrm{C}$.

\subsection{Consideration of the Reaction Mech- anism}

Figure 9 shows the conductometric titration curves for cobalt nitrate and yttrium nitrate with $\mathrm{NaOH}$ in aqueous solution. Only one inflection point was recognized, and it was the total amount of the two nitrates. On the other hand, Fig. 10 shows conductometric titration curves for cobalt nitrate and yttrium nitrate with STHB in DMF solution. The solution of $\mathrm{Y}\left(\mathrm{NO}_{3}\right)_{3}$ and $\mathrm{Co}\left(\mathrm{NO}_{3}\right)_{2}$ were mixed at the optional rate $(1: 1,1: 2$,

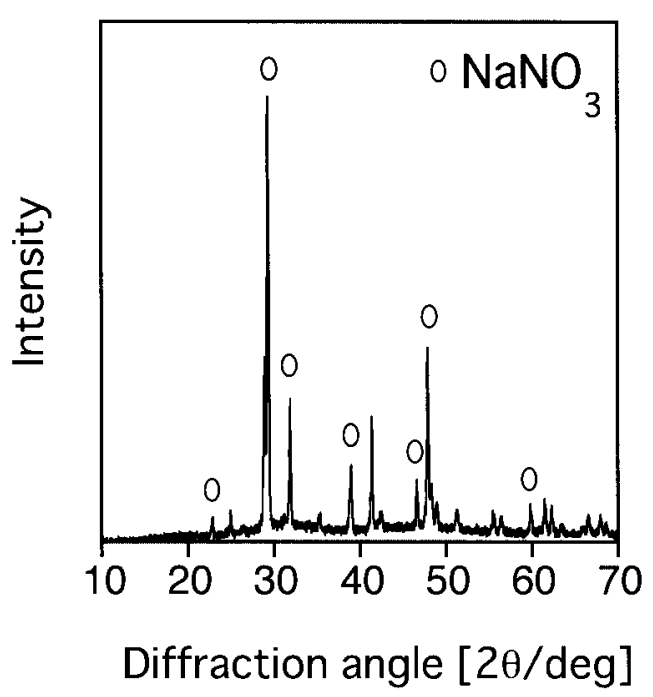

Fig. 8 X-ray Diffraction Pattern of the Residue after Having Distilled Filtrate of Cobalt( II ) under Reduced Pressure. 


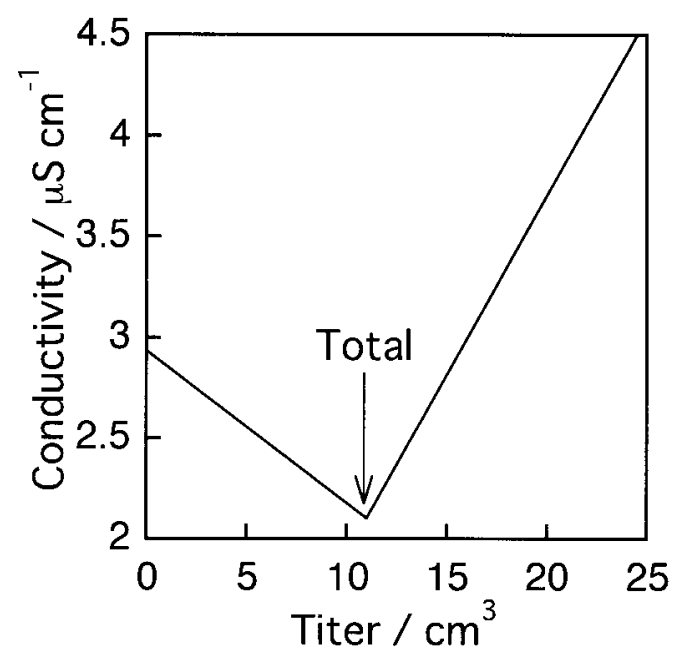

Fig. 9 Conductmetric Titration Curve of Mixed Solutions of Yttrium Nitrate and Cobalt Nitrate with Sodium Hydroxide in Aqueous Solution.

Sample : $0.05 \mathrm{M}-\mathrm{Y}\left(\mathrm{NO}_{3}\right)_{3}+0.05 \mathrm{M}-\mathrm{Co}\left(\mathrm{NO}_{3}\right)_{2} 5 \mathrm{~cm}^{3}$ Titrant : $\mathrm{NaOH} 0.05 \mathrm{M}$
2:1), and each solution was titrated with STHB solution. As a result, two inflection points were seen. The first inflection point was caused by yttrium nitrate, and the second by cobalt nitrate. Simultaneous differential determination was done by using these points. After titration of yttrium nitrate with STHB, the gel white (colorless) precipitate was separated from solution by a membrane filter. The precipitate after vacuum drying was analyzed by FT-IR by the $\mathrm{KBr}$ method. There was absorption of $\mathrm{NO}_{3}^{-}\left(1384 \mathrm{~cm}^{-1}\right)$ and $\mathrm{OH}^{-}\left(3448 \mathrm{~cm}^{-1}\right)$ on the spectra the same as with $\mathrm{Co}\left(\mathrm{NO}_{3}\right)_{2}$ (Fig. 11).

The reaction product heat-treated at $800^{\circ} \mathrm{C}$ from the XRD pattern was $\mathrm{YBO}_{3}$ (Fig. 12). It was observed that $\mathrm{Y}^{3+}$ and $\mathrm{B}^{3+}$ in the baking substance were in a ratio of $1: 1$ as a result of ICP-AES measurement. Because absorption of $\mathrm{OH}^{-}$was found as a result of FT-IR measurement, it was thought that the reaction product was the double salt of $\mathrm{Y}(\mathrm{OH})_{3}$ and $\mathrm{B}(\mathrm{OH})_{3}\left(\mathrm{YB}(\mathrm{OH})_{6}\right.$ or $\left.\mathrm{YBO}_{3} \cdot 3 \mathrm{H}_{2} \mathrm{O}\right)$. The reaction of yttrium nitrate and STHB was as follows.

$$
\begin{aligned}
& a \mathrm{Y}\left(\mathrm{NO}_{3}\right)_{3} \cdot 6 \mathrm{H}_{2} \mathrm{O}+3 a \mathrm{NaBH}_{4} \\
& \quad \rightarrow a \mathrm{YB}(\mathrm{OH})_{6} \downarrow+3 a \mathrm{NaNO}_{3}+b \mathrm{~B}_{\mathrm{m}} \mathrm{H}_{\mathrm{n}}+c \mathrm{H}_{2} \uparrow \\
& a \mathrm{Co}\left(\mathrm{NO}_{3}\right)_{2} \cdot 6 \mathrm{H}_{2} \mathrm{O}+2 a \mathrm{NaBH}_{4} \\
& \quad \rightarrow a \mathrm{CoB}(\mathrm{OH})_{5} \downarrow+2 a \mathrm{NaNO}_{3}+b \mathrm{~B}_{\mathrm{m}} \mathrm{H}_{\mathrm{n}}+c \mathrm{H}_{2} \uparrow
\end{aligned}
$$

It was thought that this reaction is a competition reaction of the neutralizing and redox. Therefore it was thought that double salt (precipitate) of $\mathrm{MB}(\mathrm{OH})_{6}[\mathrm{Oxi}-$

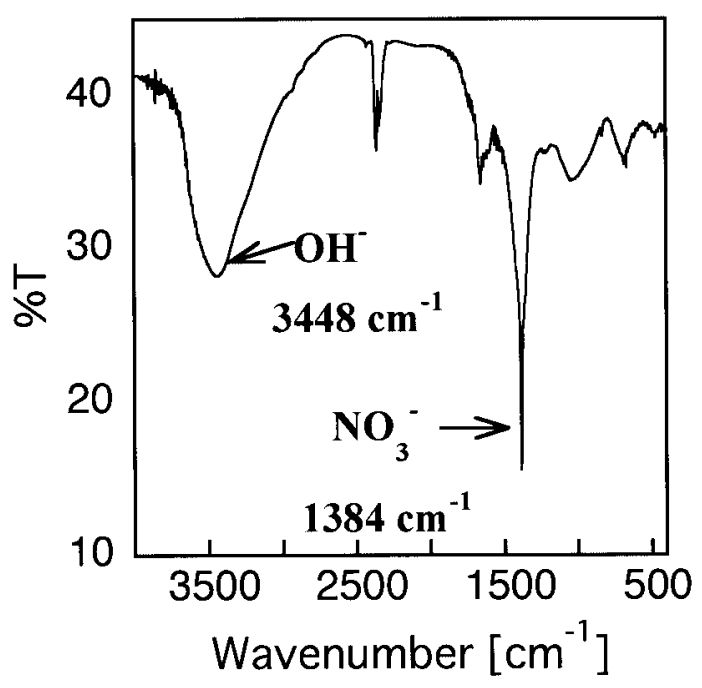

Fig. 11 FT-IR Spectrum of Precipitation Product after the Reaction of Yttrium Nitrate and Sodium Tetrahydroborate in DMF. 


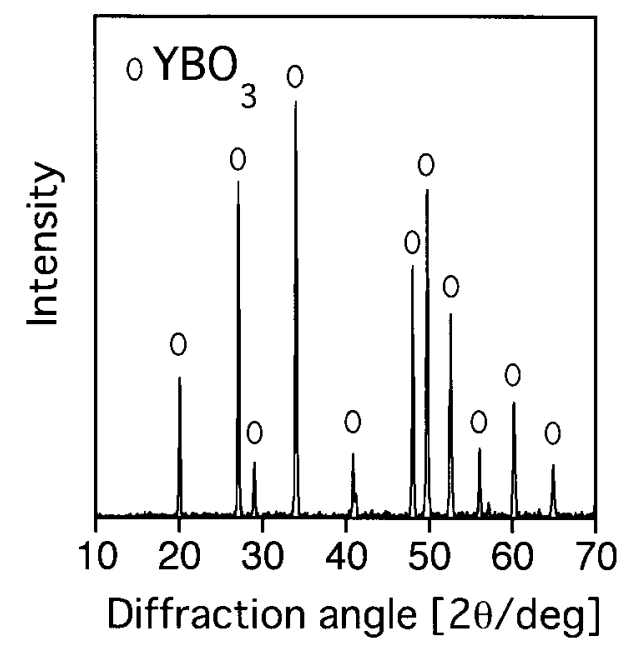

Fig. 12 X-ray Diffraction Pattern of the Residue after Heating Precipitation Product of Yttrium( III) at $800^{\circ} \mathrm{C}$.

dation number of $\mathrm{M} ;+\mathrm{III}$ ] or $\mathrm{MB}(\mathrm{OH})_{5}$ [Oxidation number of $\mathrm{M} ;+[\mathrm{I}]$ and $\mathrm{Na}_{2} \mathrm{SO}_{4}$ or $\mathrm{NaNO}_{3}$ form reaction with all metal salt and $\mathrm{NaBH}_{4}$ formed that were observed the color, the appearance and the configuration of the reaction product which has been shown with

\section{Table 1.}

The lower limit of determination with this method was about $0.005 \mathrm{~mol} \cdot \mathrm{dm}^{-3}$. Table 2 shows the results of determination by this method. The error in determination of other samples was lower than $3.0 \%$.

\section{Conclusions}

Simultaneous differential determination of inorganic acid as nitric acid and various nitrates was possible in DMF. By the conductometric titration with a nonaqueous solvent, simultaneous differential determination of two species of mixed salt hither to regarded as an impossibility in an aqueous solution became possible. The reaction mole ratio with STHB is decided by the valence of the metal ion. Differential determination is quick and simple, but separation requires much time. In particular, volumetric analysis of the rare element such as yttrium is not found in other reports.

This method is expected to be useful in the analysis of samples in which inorganic acids and metal salts included in organic solvents in the field of environment analysis.
Table 2 Analytical Results of Mixed Solution of Inorganic Acid and Nitrate.

(1) $\mathrm{HNO}_{3}+\mathrm{Ni}\left(\mathrm{NO}_{3}\right)_{2}$

\begin{tabular}{ccccc}
\hline Sample & Taken (M) & Found (M) & Error (\%) & Mole ratio \\
\hline $\mathrm{HNO}_{3}$ & $5.13 \times 10^{-2}$ & $5.07 \times 10^{-2}$ & $-1.1_{6}$ & $1: 1$ \\
\hline $\mathrm{Ni}\left(\mathrm{NO}_{3}\right)_{2}$ & $4.96 \times 10^{-2}$ & $5.02 \times 10^{-2}$ & $+1.2_{1}$ & $1: 2$ \\
\hline
\end{tabular}

(2) $\mathrm{H}_{2} \mathrm{SO}_{4}+\mathrm{Ni}\left(\mathrm{NO}_{3}\right)_{2}$

\begin{tabular}{ccccc}
\hline Sample & Taken (M) & Found (M) & Error (\%) & Mole ratio \\
\hline $\mathrm{H}_{2} \mathrm{SO}_{4}$ & $4.93 \times 10^{-2}$ & $5.04 \times 10^{-2}$ & $+2.2_{3}$ & $1: 2$ \\
\hline $\mathrm{Ni}\left(\mathrm{NO}_{3}\right)_{2}$ & $4.96 \times 10^{-2}$ & $5.10 \times 10^{-2}$ & $+2.8_{2}$ & $1: 2$ \\
\hline
\end{tabular}

\section{References}

1. C. YOSHIMURA and T. NISHIGUCHI, Nonaqueous Redox Titration of Inorganic Nitrites and Hydrogen Peroxide with Pyridine-perchloric Acid Adduct, Bunseki Kagaku, Vol. 33, 261-265 (1984).

2. C. YOSHIMURA, T. OHNISHI and A. KOBAYASHI, Redox Potentiometric Titration of Perchlorates with Tin(II) in N,Ndimethylformamide, Chemistry Express, Vol. 1, 267-270 (1986).

3. C. YOSHIMURA and K. MIYAMOTO, Redox Titration of Perchlorate and Chlorate with Titanium(III) Chloride in N,NDimethylformamide, Nippon Kagaku Kaishi, Vol. 1985, 22652270 (1985).

4. C. YOSHIMURA and T. FUJINO, Nonaqueous Conductometric Titration of Molybdenum with Hexafluorosilicic Acid, N,Ndimethylformamide Adduct, Bunseki Kagaku, Vol. 33, 48-53 (1984).

5. C. YOSHIMURA, T. FUJINO and T. OHNISHI, Conductometric Titration of Metal Chelate with EDTA in Nonaqueous Media, Bunseki Kagaku, Vol. 37, 169-173 (1988).

6. C. YOSHIMURA and Y. YAGITA, Conductometric Titration of Metal-Cupferron Chelate with EDTA in Nonaqueous Media, Bunseki Kagaku, Vol. 38, 267-271 (1989).

7. C. YOSHIMURA and K. MIYAMOTO, Determination of Metal Hydrides by Iodimetric Titration in Pyridine, Nippon Kagaku Kaishi, Vol. 1984, 1921-1926 (1984).

8. T. FUJINO, F. YOSHIKAWA and H. NOGUCHI, Simultaneous Differential Determination of Mixed Inorganic Acid by Nonaqueous Conductometric Titration with Sodium Borohydride, Bunseki Kagaku, Vol. 46, 187-193 (1997).

9. T. FUJINO, F. YOSHIKAWA and H. NOGUCHI, Simultaneous Differential Determination of Mixed Organic and Inorganic Acid by Nonaqueous Conductometric Titration with Sodium Tetrahydroborate, Bunseki Kagaku, Vol. 47, 447-450 (1998). 